\title{
Antibodies to Bluetongue, Akabane and Schmallenberg viruses in native dromedary camels in Turkey
}

\author{
Züleyha Pestill $^{1 *}$, Fırat Doğan², Kemal Gürel ${ }^{3}$, and Veysel S. Ataseven² \\ ${ }^{1}$ Institute of Pendik Veterinary Control, Viral Diagnostic Laboratory, Istanbul, Turkey \\ ${ }^{2}$ Hatay Mustafa Kemal University, Faculty of Veterinary Medicine, Department of Virology, Hatay, Turkey \\ ${ }^{3}$ Hatay Mustafa Kemal University, Graduate School of Health Sciences, Faculty of Veterinary Medicine, Department \\ of Veterinary Virology, Hatay, Turkey
}

PESTIL,Z., F. DOĞAN, K. GÜREL, V. S.ATASEVEN: Antibodies to Bluetongue, Akabane and Schmallenberg viruses in native dromedary camels in Turkey. Vet. arhiv 91, 495-501, 2021.

\section{ABSTRACT}

Sera from 86 Turkish native camels from seven provinces in Turkey were collected and tested for specific antibodies to Bluetongue virus (BTV), Akabane virus (AKAV) and Schmallenberg virus (SBV) using ELISA. The BTV, AKAV and SBV antibodies were found in $53.5 \%, 51.2 \%$ and $15.1 \%$, respectively. Furthermore, the seropositivity for multiple infection was the highest for dual infection with AKAV and BTV (25.6\%), followed by triple seropositivity (9.3\%). These findings indicated that BTV, AKAV and SBV circulate in camels in Turkey at a relatively high rate, and that an active surveillance program is needed for the management and tracing the dynamics of these infections in the Turkish camel population.

Key words: Akabane; Bluetongue; Schmallenberg; camel; seroprevalence; Turkey

\section{Introduction}

Some arthropod-borne (arbo) viruses transmitted by haematophagous flies have become increasingly widespread in recent years with the expansion of habitats of vectors depending on climate change (WHITEHORN and YACOUB, 2019). Akabane virus (AKAV), Bluetongue virus (BTV) and Schmallenberg virus (SBV), classified among nonzoonotic arboviruses, cause reproductive problems such as: early embryonic death, malformations, abortion and infertility in cattle, sheep, goat and camels (DOĞAN, 2018). BTV belongs to the genus Orbivirus in the family Reoviridae. The natural biological vectors for BTV are Culicoides spp. biting midges that transmit the virus among wild and livestock animal species (MELLOR and BOORMAN, 1995; MELLOR et al., 2000; MELLOR and WITMANN, 2002). The virus may cause a severe clinical disease characterized by oedema, haemorrhage and ulceration of mucous membranes in sheep and deer (MELLOR and BOORMAN, 1995; ERTÜRK et al., 2004; BATTEN et al., 2011). BTV infection has also been reported in camelids, such as alpaca and camel (MADANI et al., 2011; WRIGHT, 2014). In Turkey, BTV infections, recognized as serotypes 4, 8, 9 and 16,

*Corresponding author:

Züleyha Pestil, Institute of Pendik Veterinary Control, Viral Diagnostic Laboratory, Istanbul, Turkey, E-mail: zuleyhapestil@hotmail.com 
are prevalent among ruminants (ALBAYRAK and OZAN, 2010; KARAOĞLU et al., 2012; YILMAZ and ÖZKUL, 2012; PESTIL, 2014; OIE, 2018).

AKAV and SBV belong to the Simbu serogroup of the genus Orthobunyavirus in the family of Peribunyaviridae (WANG et al., 2019). Both AKAV and SBV infections are transmitted to a wide host range, including cattle, sheep, goats, camels, horses and piglets, by biting midges (Culicoides spp.) and/or mosquitoes (Aedes spp. and Culex spp.) (DE REGGE et al., 2012; MELAKU et al., 2016; PAGES et al., 2018; RASEKH et al., 2018; YANASE et al., 2018; WANG et al., 2019), causing considerable reproductive disorders in adult animals, such as abortion, mummification, stillbirth and congenital abnormalities (HOFFMANN et al., 2012; WERNIKE and BEER, 2017). SBV specific antibodies were also reported in alpaca from South American camelids (JACK et al., 2012; SCHULZ et al., 2015), in a dog (WENSMAN et al., 2013) and in ruminants, such as cattle, goats, sheep and water buffalo (HOFFMANN et al., 2012; AZKUR et al., 2013). Moreover, SBV causes a mostly subclinical infection in camels (SCHULZ et al., 2015).

Several reports on BTV, AKAV and SBV in ruminants in Turkey have provided more data on the epidemiology of these infections (ÖZGÜNLÜK, 2003; GÜR et al., 2008; KARAOĞLU et al., 2012; AZKUR et al., 2013; TONBAK et al., 2016; MACUN et al., 2017; DOĞAN, 2018; OIE, 2018), while there are a few reports about some arbovirus infections, such as epizootic haemorragic disease virus (EHDV) and West Nile virus (WNV), and AKAV infections in Turkish camels (EROL et al., 2014 and 2016; KOÇ and EROL, 2017). In this study, the prevalence of BTV, AKAV and SBV infections was investigated serologically in healthyappearing camels in various parts of Turkey, to provide new insights into the prevalence of BTV, AKAV and SBV infections in Turkish camels to guide future large-scale epidemiological studies. To the best of our knowledge, this study is the first report on the presence of antibodies to BTV and SBV in Turkish camels.

\section{Materials and methods}

Serum samples. A total of 86 sera samples obtained from clinically healthy dromedary camels
(Camelus dromaderius), unvaccinated against the investigated viruses, were randomly taken from animals in private ownerships (from volunteer animal owners) from seven provinces (Antalya, Aydın, Çanakkale, Denizli, İzmir, Muğla and Şanlıurfa) in Turkey in 2019 (Fig. 1). The sampled camels were used for wrestling, transport and touristic activities. All blood samples were taken into clot activator vacuum tubes and centrifuged at $5000 x g$ for 10 minutes, then kept at $-20{ }^{\circ} \mathrm{C}$ until testing.

Serological analysis. Commercial diagnostic ELISA kits were used for detection of BTV (IDVet Bluetongue Competitive ELISA; Pourquier Laboratory, Montpellier, France), AKAV (AKAV Antibody ELISA; JNC Corporation, Tokyo, Japan), and SBV-specific antibodies (INgezim Schmallenberg Compac 2.0, Ingenasa, Spain), as described by the manufacturers. The AKAV ELISA kit microplates were coated with the monoclonal antibody 19B-4 to the Akabane virus G1 protein. The SBV ELISA kit's conjugate also contains a specific monoclonal antibody for SBV. It was reported by the manufacturer that both the AKAV and SBV antibody kits lack cross-reactivity with Simbu serogroup viruses due to the high specificity of the monoclonal used.

\section{Results and discussion}

There was no epidemiological information about BTV in Turkish camels previously reported, although a previous serosurvey showed the presence of antibodies to other orbivirus recognized as EHDV (7.3\%) in Turkish camels in Aydin province, Turkey (EROL et al., 2014). In the current study, in the panel of 86 camel sera tested the overall seropositivity rate against BTV in the Turkish camels sampled was $53.5 \%$, although the seroprevalence of BTV has been determined to range between 0 to $76.7 \%$ in camels worldwide (EISA et al., 1979; MADANI et al., 2011; TOUIL et al., 2012; YOUSEF et al., 2012; MENTABERRE et al., 2013; MELAKU et al., 2016; SAIDI et al., 2020). However, the BTV antibody prevalence in ruminants in Turkey which vary between 4.3 and 97\% (ERTÜRK, 1994; ALBAYRAK and OZAN, 2010; KARAOĞLU et al., 2012; PESTILL, 2014; DOĞAN, 2018), and the recent outbreaks in 2018 
in Turkey were associated with the BTV-4 and BTV-8 serotypes (OIE, 2018). Furthermore, the presence of biting midges from the Culicoides spp. such as Culicoides imicola, Culicoides schultzei, Culicoides longipennis, Culicoides circumscriptus, and Culicoides obsoletus was also confirmed in the sampling area (DİK and ERGÜL, 2006; DİK et al., 2012; DOĞAN, 2018).
Moreoever, it is thought that transmission of BTV to healthy animals may be caused by direct contact, the transmission of infected blood, using the same water container, and ingestion of infected placenta (MENZIES et al., 2008; LOPEZ et al., 2010), and camels may be a possible risk factor for transmission of BTV infection to other livestock (BATEN et al., 2011; MADANI et al., 2011).

Fig. 1. The sampling areas for Turkish native camels on a map of Turkey

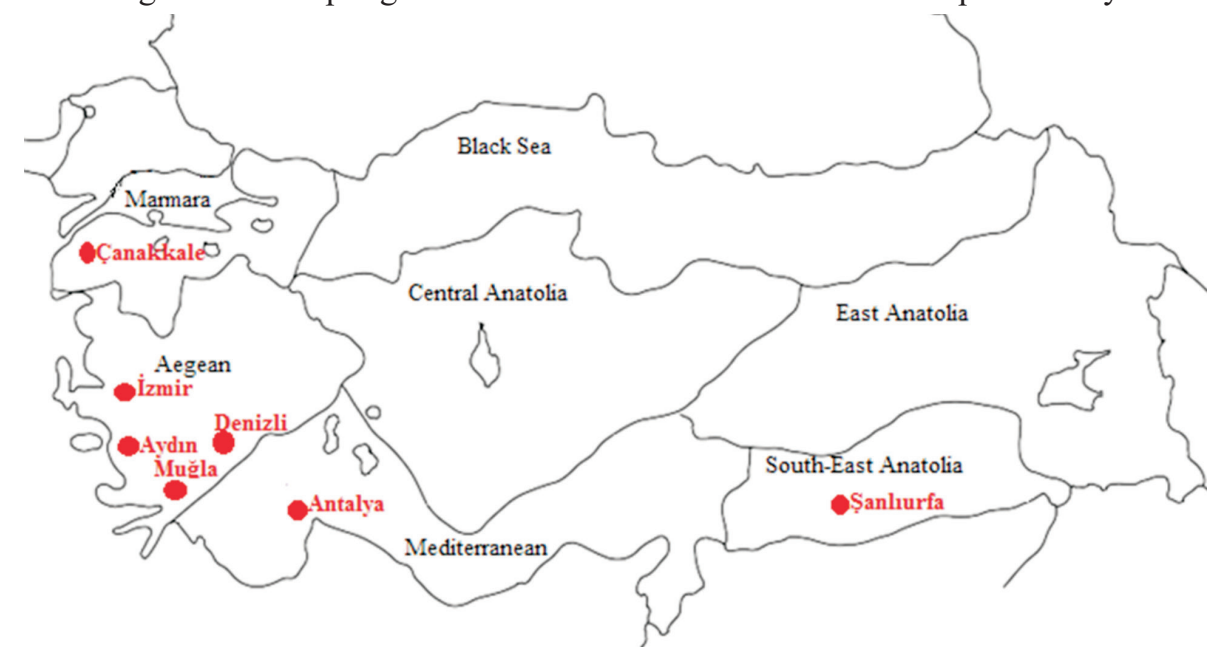

The seroprevalence of AKAV in camels has been reported to be about $0-70 \%$ worldwide (CYBINSKI et al., 1978; DAVIES and JESSETT, 1985; AL-BUSAIDY et al., 1988; MELAKU et al. 2016; KOÇ and EROL, 2017; SAIDI et al., 2020). In this study, 44 of 86 (51.2\%) Turkish camel sera samples tested were positive for AKAV antibodies. In contrast to the current findings for AKAV antibodies in Turkish camels, none of the camels sampled in the Muğla and Aydın provinces in Turkey was positive in terms of AKAV antibodies, as described by elsewhere. It is likely that the disease may be present, but could not be detected because of the low sample size or limited sampling area (KOÇ and EROL, 2017). However, on the basis of previous survey studies for AKAV infection which included the sampling areas, the seroprevalence rate for AKAV infection was reported to be up to $44.9 \%$ in ruminants in Turkey (TAYLOR and MELLOR, 1994; ÖZGÜNLÜK, 2003; ÇABALAR and DAĞALP, 2006; KARAOĞLU et al., 2007; KARAOĞLU et al., 2012; PESTILL, 2014; KOÇ and EROL, 2017; ŞEVIK, 2017; DOĞAN, 2018).
Furthermore, AKAV was isolated from Culicoides schultzei and Culicoides longipennis species in Turkey (DOĞAN, 2018). Thus, the circulation of AKAV infection in Turkish camels is also shown by current research data.

The SBV antibody prevalence rate was reported to range from $0.38 \%$ to $43.3 \%$ in ruminant populations in Turkey (AZKUR et al., 2013; MACUN et al., 2017; BIYIKLI et al., 2017; DOĞAN, 2018), and in previously published studies, the existence of $C$. obsoletus species as the main vector for SBV was also reported in Turkey (DİK and ERGÜL, 2006; DİK et al., 2012; DOĞAN, 2018). However, there was no information available for SBV in camels in Turkey and although the seroprevalence of SBV in camelids has been reported to be up to $86 \%$ worldwide there have been limited reports on the global prevalence of SBV in camelids (JACK et al., 2012; WERNERY et al., 2013; SCHULZ et al., 2015). The antibody prevalence against SBV in dromedary camels was demonstrated in Pakistan (86\%), UAE (37\%), and Sudan (19\%) (WERNERY et al., 2013). 
Z. Pestil et al.: Antibodies to Bluetongue, Akabane and Schmallenberg viruses in native dromedary camels in Turkey

Table 1. The overall seroprevalence rate of BTV, AKAV and SBV infections in Turkish camels

\begin{tabular}{|l|c|c|c|c|}
\hline Sampling Area & $\begin{array}{c}\text { Tested sera } \\
(\mathrm{n})\end{array}$ & $\begin{array}{c}\text { Ab to BTV } \\
\mathrm{n}(\%)\end{array}$ & $\begin{array}{c}\text { Ab to AKAV } \\
\mathrm{n}(\%)\end{array}$ & $\begin{array}{c}\text { Ab to SBV } \\
\mathrm{n}(\%)\end{array}$ \\
\hline Antalya & 20 & $13(65.0)$ & $7(35.0)$ & $1(5.0)$ \\
\hline Aydın & 30 & $15(50.0)$ & $14(46.7)$ & $8(30.0)$ \\
\hline Çanakkale & 7 & $2(28.6)$ & $5(71.4)$ & $1(14.3)$ \\
\hline Denizli & 14 & $7(50.0)$ & $9(64.3)$ & $1(7.1)$ \\
\hline İzmir & 6 & $4(66.7)$ & $4(66.7)$ & $1(16.7)$ \\
\hline Muğla & 2 & $2(100.0)$ & $1(50.0)$ & $1(50.0)$ \\
\hline Şanlıurfa & 7 & $3(42.8)$ & $4(57.1)$ & - \\
\hline Total & 86 & $46(53.5)$ & $44(51.2)$ & $13(15.1)$ \\
\hline
\end{tabular}

Table 2. The distribution of single and multiple infections for BTV, AKAV and SBV specific antibodies in Turkish camels

\begin{tabular}{|c|c|c|c|c|c|c|c|}
\hline $\begin{array}{l}\text { Sampling } \\
\text { Area }\end{array}$ & $\begin{array}{c}\mathrm{Ab} \text { to AKAV } \\
\mathrm{n}(\%)\end{array}$ & $\begin{array}{c}\mathrm{Ab} \text { to BTV } \\
\mathrm{n}(\%)\end{array}$ & $\begin{array}{c}\mathrm{Ab} \text { to } \mathrm{SBV} \\
\mathrm{n}(\%)\end{array}$ & $\begin{array}{c}\mathrm{Ab} \text { to AKAV } \\
\text { and BTV } \\
\mathrm{n}(\%)\end{array}$ & $\begin{array}{c}\text { Ab to } \\
\text { AKAVand SBV } \\
n(\%)\end{array}$ & $\begin{array}{c}\mathrm{Ab} \text { to BTV } \\
\text { and SBV } \\
n(\%)\end{array}$ & $\begin{array}{l}\text { Ab to all } \\
\text { viruses } \\
\mathrm{n}(\%)\end{array}$ \\
\hline $\begin{array}{l}\text { Antalya } \\
(\mathrm{n}: 20)\end{array}$ & $1(5.0)$ & $8(40.0)$ & - & $5(25.0)$ & $1(5.0)$ & - & - \\
\hline $\begin{array}{l}\text { Aydin } \\
\text { (n:30) }\end{array}$ & $4(13.3)$ & $5(16.7)$ & $2(6.7)$ & $2(6.6)$ & - & - & $6(20.0)$ \\
\hline $\begin{array}{l}\text { Çanakkale } \\
\text { (n:7) }\end{array}$ & $2(28.6)$ & - & - & $3(42.8)$ & $1(14.3)$ & - & - \\
\hline $\begin{array}{l}\text { Denizli } \\
\text { (n:14) }\end{array}$ & $4(28.6)$ & $1(7.1)$ & - & $5(35.7)$ & - & $1(7.1)$ & - \\
\hline $\begin{array}{l}\text { İzmir } \\
\text { (n:6) }\end{array}$ & - & - & - & $3(50.0)$ & - & - & $1(16.7)$ \\
\hline $\begin{array}{l}\text { Muğla } \\
(\mathrm{n}: 2)\end{array}$ & - & $1(50.0)$ & - & - & - & - & $1(50.0)$ \\
\hline $\begin{array}{l}\text { Şanliurfa } \\
\text { (n:7) }\end{array}$ & $1(14.3)$ & - & - & $3(42.8)$ & - & - & - \\
\hline $\begin{array}{l}\text { Total } \\
(\mathrm{n}: 86)\end{array}$ & $12(13.9)$ & $15(17.4)$ & $2(2.3)$ & $22(25.6)$ & $2(2.3)$ & $1(1.2)$ & $8(9.3)$ \\
\hline
\end{tabular}

In the current study, the seroprevalence rate in Turkish camels was shown for the first time to be $15.1 \%(13 / 86)$ in the tested animals. Additionally, AKAV antibodies are more prevalent than SBV in the Turkish camels in the current study. The antibody level obtained three weeks after experimental SBV infection in camelids was reported to be very low compared to cattle and sheep (SCHULZ et al., 2015). The detection of low SBV seropositivity in this study may be due to the low antibody level in camels.

The overall seroprevalence of the dual or triple infections examined was $38.4 \%$ (33/86) in Turkish camels, while the seropositivity for multiple infection was the highest for dual reactivity against AKAV and BTV (25.6\%), followed by triple seropositivity (9.3\%). Previous reports argued that the intensity of transmission in arbovirus diseases is dependent on the vectorial capacity and competence of local mosquitoes, and changes in the ecosystem and climate have impacted the transmission of a wide range of some arbovirus diseases worldwide (ROSSATI et al., 2016; SEMENZA and SUK, 2018).

In conclusion, the data revealed that BTV, AKAV and SBV circulate in camels in Turkey, although the current study shows a lower prevalence in terms of SBV compared with AKAV and BTV antibody prevalence in these camels in Turkey. Furthermore, this study provides general epidemiological information about emerging non-zoonotic arbovirus (BTV, AKAV and SBV) infections in Turkish native camels. An active monitoring program is needed to manage and monitor the dynamics of these infections in the Turkish camel population. 


\section{Conflict of interest}

None of the authors has any financial or personal relationships that could inappropriately influence or bias the content of the paper.

\section{Ethical approval}

The study protocol was approved by the Local Animal Ethics Committee of the Institute of Pendik Veterinary Control, İstanbul, Turkey (No.06/2019). Permission for publication was obtained from General Directorate of Food and Control, Ministry of Agriculture and Forestry, Republic of Turkey (09.08.2019/E.2457377)

\section{Funding}

This research did not receive any specific grant from funding agencies in the public, commercial, or not-for-profit sector.

\section{References}

ALBAYRAK, H., E. OZAN (2010): Seroprevalence of some arboviral infections transported blood sucking insects in ruminants and equids in Middle Blacksea. Kafkas Univ. Vet. Fak. Derg. 16, 33-36.

DOI: $10.9775 / \mathrm{kvfd} .2009 .341$

AL-BUSAIDY, S. M., P. S. MELLOR, W. P. TAYLOR (1988): Prevalence of neutralising antibodies to Akabane virus in the Arabian Peninsula. Vet. Microbiol. 17, 141-149.

DOI: 10.1016/0378-1135(88)90005-3

AZKUR, A .K., H. ALBAYRAK, A. RİŞVANLI, Z. PESTİL, E. OZAN (2013): Antibodies to Schmallenberg virus in domestic livestock in Turkey. Trop. Anim. Health Prod. 45, 1825-1828.

DOI: $10.1007 / \mathrm{s} 11250-013-0415-2$

BATTEN, C. A., B. HARIF, M. R HENSTOCK, S. GHIZLANE, L. EDWARDS, C. LOUTFI, C. A. OURA, M. EL HARRAK (2011): Experimental infection of camels with bluetongue virus. Res. Vet. Sci. 90, 533-535.

DOI: 10.1016/j.rvsc.2010.07.013

BIYIKLI, E., A. K. AZKUR, Ș. TONBAK, H. C. MACUN (2017): Monitoring Schmallenberg virus specific maternal antibodiesincalves. FiratUniv.Vet.J.HealthSci.31,189-192.

CYBINSKI, D. H., T. D. GEORGE; N. I. PAULL (1978): Antibodies to Akabane virus in Australia. Aust. Vet. J. 54, $1-3$.

DOI: 10.1111/j.1751-0813.1978.tb00256.x

ÇABALAR, M., S. B. DAĞALP (2006): Seroprevalence of Bluetongue and Akabane diseases in dairy cattle in SouthEast Turkey. Slovenian Vet. Res. 43, 296-297.

DAVIES, F. G., D. M. JESSETT (1985): A study of the host range and distribution of antibody to Akabane virus (genus Bunyavirus, family Bunyaviridae) in Kenya. J. Hyg. 95 , 191-196.

DOI: $10.1017 / \mathrm{s} 0022172400062422$
DE REGGE, N., I. DEBLAUWEI, R. DE DEKEN, P. VAINTIEGHEM, M. MADDER, D. GEYSEN (2012): Detection of Schmallenberg virus in different Culicoides spp. by real-time RT-PCR. Transbound. Emerg. Dis. 59, 471-475.

DOI: $10.1111 /$ tbed. 12000

DİK, B., R. ERGÜL (2006): Nocturnal flight activities of Culicoides (Diptera: Ceratopogonidae) species in Konya. Acta Parasitol. Turcica 30, 213-216.

DİK, B., S. YAVRU, U. USLU, O. YAPICI, E. ESIN (2012): Determination of Culicoides species (Diptera: Ceratopogonidae) as suspect vectors of epizootic haemorragic disease and blue-tongue viruses in southern and western Anatolia by RT-PCR. Revue Med. Vet. 163, 505-510.

DOĞAN, F. (2018): Epidemiological investigation and possible vector identification of ruminant some arboviral infections (Akabane, Bluetongue and Schmallenberg virus) in Hatay province. Dissertation, University of Ankara, Turkey.

EISA, M., A. E. KARRAR, A. H. ABDELRAHIM (1979): Incidence of Bluetongue virus precipitating antibodies in sera of some domestic animals in the Sudan. J. Hyg. 83, 539-545.

DOI: $10.1017 / \mathrm{s} 0022172400026395$

EROL N., M. GÜRÇAY, S. KIRDAR, B. ERTUĞRUL, S. GÜR, B.T . KOÇ, M. T. TAN (2016): A serological investigation of West Nile virus infections in various animal species and humans in western Turkey. Israel J. Vet. Med. 71, 42-46.

EROL, N., M. T. TAN, B. T. KOÇ (2014): A serological investigation of epizootic hemorragic disease virus infection in sheep, goats and camels in the Aydin province. International VETistanbul Group Congress, 28-30 April 2014, Istanbul, Turkey.

ERTÜRK, A. (1994): The detection of blue-tongue antibodies (sheep-goat-cattle) in various blood sera by using agar-gel precipitation test. J. Etlik Vet.Microbiol. 7, 1-19.

ERTÜRK, A., N. TATAR, O. KABAKLI, S. İNÇOGLU, Ş. G. ÇİZMECI, F. M. BARUT (2004): The current situation of bluetongue in Turkey. Vet. Ital. 40, 137-140.

GÜR, S. (2008): A serologic investigation of Bluetongue virus (BTV) in cattle, sheep and gazella subgutturosa in southeastern Turkey. Trop. Anim. Health Prod. 40, 217-221. DOI: $10.1007 / \mathrm{s} 11250-007-9083-4$

HOFFMANN, B., M. SCHEUCH, D. HÖPER, R. JUNGBLUT, M. HOLSTEG, H. SCHIRRMEIER, M. ESCHBAUMER, K. V. GOLLER, K. WERNIKE, M. FISCHER, A. BREITHAUPT, T. C. METTENLEITER, M. BEER (2012): Novel orthobunyavirus in cattle, Europe, 2011. Emerg. Infect. Dis. 18, 469-472.

DOI: $10.3201 /$ eid1803.111905

JACK. C., O. ANSTAETT, J. ADAMS, R. NOAD, J. BROWNLIE, P. MERTENS (2012): Evidence of seroconversion to SBV in camelids. Vet. Rec. 170, 602-603. DOI: $10.1136 /$ vr.e3939 
KARAOĞLU, T., İ. ÖZGÜNLÜK, B. DEMİR, A. ÖZKUL, İ. BURGU (2007): Seroprevalence of Culicoides-borne disease in cattle in European Turkey. Ankara Univ. Vet. Fak. Derg. 54, 121-125.

KARAOĞLU, M. T., İ. ÖZGÜNLÜK, Y. YILDIRIM, E. GÜNGÖR, T. C.. OĞUZOĞLU, S. B. DAĞALP, A. ÖZKUL, F. ALKAN, Y. AKÇA, İ. BURGU (2012): Seroepidemiology of Bluetongue virus infection in Northeast and Southeast Anatolia, Turkey. Ankara Univ. Vet. Fak. Derg. 59, 289-294.

KOÇ, B. T., N. EROL (2017): The serological investigation of Akabane virus (AKAV) infection in cattle, sheep, goats and camels in Aydın and Muğla provinces. Anim. Health Prod. Hyg. 6, 459-462.

LOPEZ-OLVERA J. R., C. FALCONI, P. FERNANDEZPACHECO (2010): Experimental infection of European red deer (Cervus elaphus) with bluetongue virus serotypes 1 and 8. Vet. Microbiol. 145, 148-152.

DOI: $10.1016 /$ j.vetmic.2010.03.012

MACUN, H. C., A. K. AZKUR, H. KALENDER, S. ERAT (2017): Seroprevalance of Schmallenberg virus and its relationship with some geographical features in sheep reared in Kırıkkale. Ankara Univ. Vet. Fak. Derg. 64, 93-97.

MADANI, H., J. CASAL, A. ALBA, A. ALlEPUZ, C. CÊTRE-SOSSAH, L. HAFSI, H. KOUNT-CHAREB, N. BOUAYED-CHAOUACH, H. SAADAOUI, S. NAPP (2011): Animal diseases caused by orbiviruses, Algeria. Emerg. Infect. Dis. 17, 2325-2327.

DOI: $10.3201 /$ eid1712.110928

MELAKU, S. K., F. REGASSA, T. S. TESSEMA, F. DAWO, K. OGUMA, K. NAGAYAMA, H. SENTSUI (2016): Serological survey of viral diseases relating to reproductive failure among Artiodactyla in Ethiopian Camelus dromedarius. Microbiol. Immunol. 60, 506-510.

DOI: $10.1111 / 1348-0421.12394$

MELLOR, P., S. E. J. WITTMANN (2002): Bluetongue virus in the Mediterranean Basin 1998-2001. Vet. J. 164, 20-37. DOI: $10.1053 /$ tvj1.2002.0713

MELLOR, P., S, J. BOORMAN, M. BAYLIS (2000): Culicoides biting midges: their role as arbovirus vectors. Annu. Rev. Entomol. 4, 307-340.

DOI: 10.1146/annurev.ento.45.1.307

MELLOR, P., S, J. BOORMAN (1995): The transmission and geographical spread of African horse sickness and Bluetongue viruses. Ann. Trop. Med. Parasit. 89, 1-15.

DOI: $10.1080 / 00034983.1995 .11812923$

MENTABERRE, G., C. GUITERREZ, N. F. RODRIGUEZ, S. JOSEPH, D. GONZÁLEZ-BARRIO, O. CABEZÓN, J. DE LA FUENTE, C. GORTAZAR, M. BOADELLA (2013): A transversal study on antibodies against selected pathogens in dromedary camels in the Canary Islands, Spain. Vet. Microbiol. 167, 468-473.

DOI: 10.1016/j.vetmic.2013.07.029
MENZIES, F. D., S. J. MCCULLOUGH, I. M. MC KEOWN, J. L. FORSTER, S. JESS, C. BATTEN, A. K. MURCHIE, J. GLOSTER, J. G. FALlOWS, W. PELGRIM, P.S. MELLOR, C.A. OURA(2008): Evidence for transplacental and contact transmission of Bluetongue virus in cattle. Vet. Rec. 163, 203-209.

DOI: $10.1136 /$ vr.163.7.203

OIE (2018): Weekly disease information, Vol. 31, No.47, November 2018. https://www.oie.int/wahis_2/public/ wahid.php/Reviewreport/Review?reportid $=28691$

ÖZGÜNLÜK, İ. (2003): Seroepidemiological investigation of bluetongue (BT), Akabane (AKA) and Ibaraki (IBA) disease in cattle in Southeastern Project (GAP) area. Dissertation, University of Ankara, Turkey (in Turkish).

PAGES, N., S. TALAVERA, M. VERDUN, N. PUJOL, M. VALLE, A. BENSAID, J. PUJOLS (2018): Schmallenberg virus detection in Culicoides biting midges in Spain: First laboratory evidence for highly efficient infection of Culicoides of the Obsoletus complex and Culicoides imicola. Transbound. Emerg. Dis. 65, e1-e6.

DOI: $10.1111 /$ tbed.12653

PESTIL, Z. (2014): Investigation of the viruses (pestivirus, bluetongue and akabane virus) in abortion and postnatal samples from sheep in Marmara region. Dissertation, University of Firat, Turkey (in Turkish).

RASEKH, M., A. SARANI, S. H. HASHEMI (2018): Detection of Schmallenberg virus antibody in equine population of Northern and Northeast of Iran. Vet. World 11, 30-33. DOI:10.14202/vetworld.2018.30-33

ROSSATI, A., O. BARGIACCHI, V. KROUMOVA, M. ZARAMELLA, A. CAPUTO, P. L. GARAVELLİ (2016): Climate, environment and transmission of malaria. Infez. Med. 24, 93-104.

SAIDI, R., F. DOĞAN, V. S. ATASEVEN, Y. ERGÜN (2020): Antibody detection against Akabane (AKA) and Bluetongue (BT) viruses in Algerian dromedary camels. Turk. J. Vet. Anim Sci. 44, 142-145.

DOI: $10.3906 /$ vet-1905-44

SCHULZ, C., M. BEER, B. HOFFMANN (2015): Schmallenberg virus infection in South American camelids: Field and experimental investigations. Vet. Microbiol. 180, 171-179.

DOI: $10.1016 /$ j.vetmic.2015.08.024

SEMENZA, J. C., J. E. SUK (2018): Vector-borne diseases and climate change: a European perspective. FEMS Microbiol. Lett. 365(2):fnx244.

DOI: $10.1093 /$ femsle/fnx244

ŞEVIK, M. (2017): Molecular detection and serological survey of Akabane virus infection in sheep in the Mediterranean region of Turkey. Small Rumin. Res. 156, 1-6.

DOI:10.1016/j.smallrumres.2017.07.012 
TAYLOR, W. P., P. S. MELLOR (1994): The distribution of Akabane virus in the Middle East. Epidemiol. Infect. 113:175-185.

DOI: $10.1017 / \mathrm{S} 0950268800051591$

TONBAK, Ş., A.K. AZKUR, Z. PESTILl, E. AKSOY, H. ABAYLI, E. BAYDAR, W. H. M. VAN DER POEL, H. BULUT (2016): Circulation of Schmallenberg virus in Turkey, 2013. Turkish J. Vet. Anim. Sci. 40, 175-180. DOI:10.3906/vet-1507-3

TOUIL, N., Z. CHERKAOUI, Z. LMRABIH, C. LOUTFI, B. HARIF, M. EL HARRAK (2012): Emerging viral diseases in dromedary camels in the Southern Morocco. Transbound. Emerg. Dis. 59, 177-182.

DOI:10.1111/j.1865-1682.2011.01282.x

WANG, J., C. FIRTH, R. AMOS-RITCHIE, S. S. DAVIS, H. YIN, E. C HOLMES, K. R. BLASDELL, P. J. WALKER (2019): Evolutionary history of Simbu serogroup orthobunyaviruses in the Australian episystem. Virology 535:32-44.

DOI:10.1016/j.virol.2019.06.013

WENSMAN, J. J., G. BLOMQVIST, M. HJORT, B. S. HOLST (2013): Presence of antibodies to Schmallenberg virus in a dog in Sweden. J. Clin. Microbiol. 51, 2802-2803. DOI:10.1128/JCM.00877-13

WERNERY, U., R. THOMAS, R. RAGHAVAN, G. SYRIAC (2013): Serological evidence of epizootic haemorrhagic disease and schmallenberg virus in dromedaries. J. Camel Pract. Res. 20, 135-137.

WERNIKE, K., M. BEER (2017): Schmallenberg virus: a novel virus of veterinary importance. Adv. Virus Res. 99:39-60.

DOI: 10.1016/bs.aivir.2017.07.001
WHITEHORN, J., S. YACOUB (2019): Global warming and arboviral infections. Clin. Med. 19, 149-152.

DOI: $10.7861 /$ clinmedicine.19-2-149

WRIGHT, I. M. (2014): Serological and genetic characterisation of putative new serotypes of bluetongue virus and epizootic haemorragic disease virus isolated from an Alpaca. Dissertation, North-West University, Potchefstroom Campus.

YANASE, T., T KATO, Y. HAYAMA, M. AKIYAMA, N. ITOH, S. HORIUCHI, Y. HIRASHIMA, H. SHIRAFUJ, M. YAMAKAWA, S. TANAKA, T. TSUTSUI (2018): Transition of Akabane virus genogroups and its association with changes in the nature of disease in Japan. Transbound. Emerg. Dis. 65, e434-e443.

DOI: $10.1111 /$ tbed. 12778

YILMAZ, V., A. ÖZKUL (2012): Serotypic identification of local bluetongue virus isolates using Plaque Reduction Neutralization (PRN) and Reverse Transcriptase Polymerase Chain Reaction (RT-PCR) Techniques. Ankara Univ. Vet. Fak. Derg. 59, 35-40.

YOUSEF, M. R., A. A. AL-EESA, M. H. AL-BLOWI (2012): High seroprevalence of bluetongue virus antibodies in sheep, goats, cattle and camel in different districts of Saudi Arabia. Vet. World 5, 389-393.

DOI:10.5455/vetworld.2012.389-393

PESTIL, Z., F. DOĞAN, K. GÜREL, V. S. ATASEVEN: Protutijela na virus plavog jezika, virus akabane i virus Schmallenberg u lokalnih dromedarskih deva Turske. Vet. arhiv 91, 495-501, 2021.

\section{SAŽETAK}

Prikupljeni su uzorci seruma od 86 dromedarskih deva iz sedam pokrajina Turske. ELISA testom istražena su specifična protutijela na virus plavog jezika (BTV), virus akabane (AKAV) i virus Schmallenberg (SBV). Protutijela na BTV pronađena su u 53,5 \% uzoraka, na AKAV u 51,2 \% uzoraka, a na SBV u 15,1\% uzoraka. Seropozitivnost za višestruku infekciju najveća je bila u slučaju dvojnih infekcija AKAV-om i BTV-om (25,6 \%), a slijedi je trostruka seropozitivnost (9,3\%). Ovi rezultati upućuju na to da je stopa pojavnosti BTV-a, AKAV-a i SBV-a u deva u Turskoj relativno visoka te je potreban aktivan program nadzora i upravljanja dinamikom ovih infekcija.

Ključne riječi: virus akabane; virus plavog jezika; virus Schmallenberg; seroprevalencija; deva; Turska 
